\title{
Medicinal plants possess sedative and anxiolytic effect with emphasis on their mechanisms of action
}

\author{
Ali Esmail Al-Snafi * \\ Department of Pharmacology, College of Medicine, University of Thi-Qar, Iraq.
}

GSC Biological and Pharmaceutical Sciences, 2021, 17(03), 061-077

Publication history: Received on 01 November 2021; revised on 10 December 2021; accepted on 12 December 2021

Article DOI: https://doi.org/10.30574/gscbps.2021.17.3.0351

\begin{abstract}
Insomnia and anxiety are worldwide medical problems. Plant extracts possessed sedative and anxiolytic effect via different mechanisms included interactions with $\mathrm{Na}+$ channels, $\gamma$-aminobutyric acid type A receptors, N-methyl-Daspartate receptors and chatecholamines. In the current review, Web Science, PubMed, Scopus and Science Direct, were searched to investigate the plants with sedative and anxiolytic effects
\end{abstract}

Keywords: Insomnia; Anxiety; Sedative; Anxiolytic; Medicinal Plants

\section{Introduction}

Insomnia and anxiety are worldwide medical problems. Many medicinal plants were used traditionally to treat CNS problems [1-2]. The recent reviews showed that medicinal plants possessed muscle relaxant, anticonvulsant, antidepressants, anti-Parkinsonian, neuroprotective and memory enhancement effects. The interactions with $\mathrm{Na}^{+}$ channels, $\gamma$-aminobutyric acid type A receptors, N-methyl-D-aspartate receptors and chatecholamines could represent the mechanisms of sedative and anxiolytic effects of medicinal plant extracts [3-10]. The current review was designed to highlight the medicinal plants with sedative and anxiolytic effect with emphasis on their mechanisms of action.

\section{Plant with sedative and anxiolytic effects}

\subsection{Anthemis nobilis}

In mice, apigenin had a clear affinity for central benzodiazepine receptors. Apigenin competitively inhibited the binding of flunitrazepam, a benzodiazepine, but had no effect on muscarinic receptors, alpha 1-adrenoceptors, or the binding of muscimol to GABA receptors. Apigenin had clear anxiolytic activity in mice without incidence of sedation or muscle relaxation effects at doses similar to those used for classical benzodiazepines; no anticonvulsant action was detected. Increasing dosages produced mild sedation and a reduction in ambulatory locomotor activity [11-13].

\subsection{Arachis hypogaea}

Arachis hypogaea leaf aqueous extracts have received a long reputation as an abirritative remedy to ease various sleep disorders. The clinical studies confirmed the hypnotic effects of Arachis hypogaea [14-15]. The sedative effects of Arachis hypogaea leaf aqueous extracts on brain ATP, AMP, adenosine and glutamate/GABA of rats was investigated. Intragastrically administrated Arachis hypogaea leaf aqueous extracts( PLAE , 100 and $500 \mathrm{mg} / \mathrm{kg}$ body weight BW) and peanut stem aqueous extracts (PSAE, $500 \mathrm{mg} / \mathrm{kg} \mathrm{BW}$ ) for at least 14 days showed that brain lactate were significantly elevated $(p<0.05)$ in rat cerebrums after PLAE administrations, compared with control and PSAE groups. A significant

\footnotetext{
${ }^{*}$ Corresponding author: Ali Esmail Al-Snafi

Department of Pharmacology, College of Medicine, University of Thi-Qar, Iraq.

Copyright $@ 2021$ Author(s) retain the copyright of this article. This article is published under the terms of the Creative Commons Attribution Liscense 4.0
} 
degradation of the brain adenosine triphosphate (ATP) $(p<0.05)$ was observed in the brain-stems and even the whole brains of rats of PLAE treatments. Moreover, the brain adenosine monophosphate (AMP) were clearly decreased $(p<$ $0.05)$ in rat cerebrum and brainstem regions, while the brain adenosine revealed an increasing propensity $(p=0.076)$ in the cerebrums of freely behaving rats. The $\gamma$-aminobutyric acid (GABA) concentrations were statistically $(p<0.05)$ enhanced and the ratios of Glutamate/GABA were simultaneously reduced $(p<0.05)$ in rat brainstems, no matter which dose (100 or $500 \mathrm{mg} / \mathrm{kg}$ BW) of PLAE were used [16-17].

\subsection{Arctium lappa}

The anti-fatigue effect of the extract of Arctium lappa L. was studied in male mice by forced swimming test. The swimming time of mice treated by 4 and $6 \mathrm{~g} / \mathrm{kg}$ of an extract of Arctium lappa was significantly prolonged as compared with control group. The hepatic glycogen storage in the groups treated with 2, 4 and $6 \mathrm{~g} / \mathrm{kg}$ of Arctium lappa extract was significantly increased. Lactic acid clearance in the groups treated with 4, and $6 \mathrm{~g} / \mathrm{kg}$ of Arctium lappa extract was significantly accelerated after mice swimming [18-19].

\subsection{Asparagus officinalis}

Asparagus officinalis exerted antifatigue effects, enhanced anoxia tolerance, induced analgesia and improved memory, as well as decreased the contents of lipid peroxide in plasma, liver and brain of the animal [20-21].

\subsection{Avena sativa}

An extract of wild green oat (Avenasativa L.), was tested in vivo in rats for its behavioural effects after chronic oral administration via extract-admixed food. Rats received $10 \mathrm{~g} / \mathrm{kg}$ and $100 \mathrm{~g} / \mathrm{kg}$ extract-admixed food showed slight decreased food and fluid intake in the high dose group, with no side effects observed during the treatment. The low dose led to an improvement of active stress response, an enhancement of shock avoidance learning and an increased synchrony in social behavior [22].

Dietary oat $\beta$-glucan enhanced the endurance capacity of rats and facilitated their recovery from stress and fatigue. Sparsgue-Dawley rats, fed with/without oat $\beta$-glucan $312.5 \mathrm{mg} / \mathrm{kg} /$ day for 7 weeks, were subjected to run on a treadmill system to make them exhausted. All rats were immediately sacrificed after prolonged exercise, and the major metabolic substrates were measured in serum and liver. The results showed feeding dietary oat $\beta$-glucan to rats significantly reduce the body weight and increase the maximum running time compared with normal control $(\mathrm{P}<0.05)$. Furthermore, dietary oat $\beta$-glucan decreased the levels of blood urea nitrogen, lactate acid, and creatine kinase activity in serum, and increased the levels of non-esterified fatty acids, lactic dehydrogenase activity in serum, and the content of liver glycogen [23].

Avenasativa improved overall mental fitness and supported cognitive performance in stressful situations. Avenasativa has been shown to positively affect the activity of brain enzymes closely related to mental health and cognitive function in-vitro. Additionally, preclinical and clinical studies have confirmed that Avena sativa specifically interacted with brain structures and neurotransmitters implicated in cognition, memory and motivation. Avena sativa boasted a dual activity profile on monoamino oxidase-B( MAO-B) and phosphodiestrase 4 (PDE4)thus displayed in its ability to meditate a strengthening and balancing effect on the brain and mind [24-25].

\subsection{Bacopa monniera}

Crude plant extract of Bacopa monnieri or bacosides have also shown anxiolytic effects, antidepressant activity, anticonvulsive action and antioxidant activity [26].

Bacopa monnieri was highly effective as an adaptogen, it normalized acute and chronic stress induced corticosterone changes in rats. It also normalized noradrenalin (NA), 5-HT, and DA in cortex and hippocampus of rats in acute and chronic unpredictable stress [27].

Bacopa monniera lowered norepinephrine and increases the 5-hydroxytryptamine levels in hippocampus, hypothalamus and cerebral cortex. The higher doses of Bacopa monniera extracts produced significantly greater anxiolytic effects compared to lorazepam, a standard anxiolytic drug from benzodiazepine group [28]. However, acute and sub chronic (one week) treatment of Bacopa monnieri methanolic extract (10, 20 or $30 \mathrm{mg} / \mathrm{kg}$ ) didn't affected dopamine (DA) and serotonin (5-HT) turnover in mice whole brain [29-30]. 


\subsection{Ballota nigra}

Phenylpropanoid derivatives isolated from Ballota nigrashowed neurosedative activity and exhibit potent antioxidant activities which are of therapeutic interest [31-32]. The ability of five phenylpropanoids (verbascoside, forsythoside B, arenarioside, ballotetroside, and caffeoyl malic acid) isolated from a hydroalcoholic extract, to bind to benzodiazepine, dopaminergic, and morphinic receptors was investigated. To carry out these studies, affinity tests with rat striata, entire brains and receptor rich preparations were employed. Results show that four of the five compounds are able to bind to the studied receptors. Inhibitory concentrations at $50 \%$ were determined and vary from 0.4 to $4.7 \mathrm{mg} / \mathrm{ml}$. This may be in relation with the Ballota nigra known neurosedative activities [33-34].

\subsection{Bryophyllum calycinum}

The methanolic extract of Bryophyllum calycinum Salisb showed neuro-pharmacological effects in experimental animals (rats and mice). The fraction produced alteration of behavior pattern, caused dose-dependent potentiation of pentobarbitone sleeping time and had significant analgesic activity and possesses a potent CNS depressant action. The saline leaf extract of Bryophyllum calycinum Salisb produced a dose-dependent prolongation of onset and duration of pentobarbitone-induced hypnosis, reduction of exploratory activities in the head-dip and evasion tests. Moreover, a dose-dependent muscle in-coordination was observed in the inclined screen, traction and climbing tests in mice. The saline leaf extract produced a dose-dependent prolongation of onset and duration of pentobarbitone-induced hypnosis, reduction of exploratory activities in the head-dip and evasion tests and a dose-dependent muscle incoordination in the inclined screen, traction and climbing tests [35-37].

\subsection{Caesalpinia crista}

The anxiolytic activities of seed extract of Caesalpinia crista in experimental animals, mice and rats were investigated by stair-case model, Three doses $(400,600$ and $800 \mathrm{mg} / \mathrm{kg}$ ) showed a significant and dose dependent anxiolytic activity by increasing the number of steps climbed, without any significant effect on rearings by all the three doses. Similarly in EPM model medium, high doses, but not the low dose had significantly enhanced both number of entries and time spent in open arms and decreased in number of entries and time spent in closed arms. In Hole- board model, medium and high doses 600 and $800 \mathrm{mg} / \mathrm{kg}$ but not the low dose $400 \mathrm{mg} / \mathrm{kg}$ had significantly enhanced the number, latency and the duration of head dipping but not the rearings. However in LDT model high doses $800 \mathrm{mg} / \mathrm{kg}$ had significantly exhibited anxiolytic activity by increasing time spent, number of crossings in light compartment and decreased the time spent in dark compartment and decreased the number of rearings in both light and dark compartments. In OFT models, medium and high doses 600 and $800 \mathrm{mg} / \mathrm{kg}$ but not the low dose $400 \mathrm{mg} / \mathrm{kg}$ had significantly enhanced total locomotion, central locomotion, number of grooming but the immobility time has drastically reduced. All doses have not exerted any significant effect with rearing, defecation and urination. Moreover in Mirror-chamber model of anxiety, both medium and high doses 600 and $800 \mathrm{mg} / \mathrm{kg}$ but not the low dose $400 \mathrm{mg} / \mathrm{kg}$ had significantly reduced the time latency to enter into the mirror chamber and increased the number of entries and time spent in the chamber. These result confirmed the anxiolytic activity of Caesalpiniacrista [38].

Caesalpinia crista seed extracts were screened for adaptogenic activity using cold stress and swim endurance models. The seed coat as well as kernel extracts administered orally at a dose of $300 \mathrm{mg} / \mathrm{kg}$ significantly increased the swim endurance time. The extracts also corrected hyperglycemia, the depletion in serum cortisol level, increased total leukocyte count, and controlling the hyperlipidaemic condition associated with to stress [39-40].

\subsection{Carum carvi}

The aqueous extract of Carum carvi was evaluated for antistress activity in normal and stress induced rats. The extract was studied for nootropic activity in rats and in vitro antioxidant potential to be correlated with its antistress activity. For the evaluation of antistress activity groups of rats were subjected to forced swim stress one hour after daily treatment of Carum carvi extract. Urinary vanillylmandelic acid (VMA) and ascorbic acid were selected as non invasive biomarkers to assess the antistress activity. The $24 \mathrm{~h}$ urinary excretion of vanillylmandelic acid (VMA) and ascorbic acid was determined in all groups under normal and stressed conditions. The nootropic activity of the extract as determined from acquisition, retention and retrieval in rats was studied by conditioned avoidance response using Cook's pole climbing apparatus. Daily administration of Carum carvi at doses of 100, 200 and $300 \mathrm{mg} / \mathrm{kg}$ body weight one hour prior to induction of stress inhibited the stress induced urinary biochemical changes in a dose dependent manner. However no change in the urinary excretion of VMA and ascorbic acid was observed in normal animals. The cognition, as determined by the acquisition, retention and recovery in rats was observed to be dose dependent. The in vitro antioxidant activity was determined based on the ability of Carum carvi to inhibit lipid peroxidation in liver and brain homogenates. The extract produced significant inhibition of lipid peroxide formation in comparison with ascorbic acid in a dose dependent manner in both liver and brain [41-42]. 


\subsection{Citrus species}

The effects of apigenin, a bioflavonoid widely found in citrus fruits, on behavioral changes and inflammatory responses induced by chronic unpredictable mild stress (CUMS) was investigated in rats. When GW9662, a selective peroxisome proliferator-activated receptor gamma (PPAR $\gamma$ ) inhibitor, administered $30 \mathrm{~min}$ before apigenin, apigenin $(20 \mathrm{mg} / \mathrm{kg}$, intragastrically) for three weeks remarkably ameliorated CUMS-induced behavioral abnormalities, such as decreased locomotor activity and reduced sucrose consumption. In response to oxidative stress, the NLRP3 inflammasome was activated and IL-1 $\beta$ secretion increased in the prefrontal cortex (PFC) of CUMS rats. However, apigenin treatment upregulated PPAR $\gamma$ expression and downregulated the expression of NLRP3, which subsequently downregulated the production of IL-1 $\beta$. In addition, GW9662 diminished the inhibitory effects of apigenin on the NLRP3 inflammasome. Accordingly, the results demonstrated that apigenin exhibited antidepressant-like effects in CUMS rats, possibly by inhibiting IL-1 $\beta$ production and NLRP3 inflammasome expression via the up-regulation of PPAR $\gamma$ expression [43].

The sedative effects of essential oil (EO) of leaves from Citrus limon were investigated in mice. EO $150 \mathrm{mg} / \mathrm{kg}$, orally significantly increased the animals sleeping time duration [44].

The effects of Citrus sinensis essential oil was evaluated in the elevated plus-maze followed by the light/dark paradigm in rats. The animals were exposed to the orange aroma $(100,200$ or 400 microl) for $5 \mathrm{~min}$, while in a Plexiglas chamber and were then immediately submitted to the behavioural tests. At all doses, $C$ sinensis oil demonstrated anxiolytic activity in at least one of the tests and, at the highest dose, it presented significant effects in both animal models, as indicated by increased exploration of the open arms of the elevated plus-maze (time: $p=0.004$; entries: $p=0.044$ ) and of the lit chamber of the light/dark paradigm (time: $p=0.030$ ). In order to discard the possibility that this outcome was due to non-specific effects of any odour exposure, the behavioural response to Melaleuca alternifolia essential oil was also evaluated, using the same animal models, but no anxiolytic effects were observed [45-46].

\subsection{Coriandrum sativum}

The anxiolytic effect of aqueous extract $(50,100,200 \mathrm{mg} / \mathrm{kg}$, ip) was examined in male albino mice using elevated plusmaze as an animal model of anxiety. In the elevated plus-maze, aqueous extract at $200 \mathrm{mg} / \mathrm{kg}$ showed an anxiolytic effect by increasing the time spent on open arms and the percentage of open arm entries, compared to control group [47-48].

The anxiolytic effect of Coriandrum sativum (CS) aqueous extract was evaluated in mice. The antianxiety effect was assessed by elevated plus maze (EPM). In EPM, 50,100, and $200 \mathrm{mg} / \mathrm{kg}$ of CS were significantly $(\mathrm{P}<0.001)$ increases the number of entries in open arms compared to control. The time spent in open arms also increased in all the doses of CS extract significantly [49].

The anti-anxiety activity of hydroalcoholic extract of Coriandrum sativum was studied using different animal models (elevated plus maze, open field test, light and dark test and social interaction test) of anxiety in mice. Diazepam (0.5 $\mathrm{mg} / \mathrm{kg}$ ) was used as astandard drug and hydroalcoholic extract of Coriandrum sativum fruit was used in dose of (50, 100 and $200 \mathrm{mg} / \mathrm{kg}$ ) to study the antianxiety effect. Results revealed that the extract of Coriandrum sativum at 100 and $200 \mathrm{mg} / \mathrm{kg}$ dose produced anti-anxiety effects almost similar to diazepam, while, at $50 \mathrm{mg} / \mathrm{kg}$ dose, it did not produce anti-anxiety activity in all models [50].

The anxiolytic effect of the aqueous extract of Coriandrum sativum seed and its effect on spontaneous activity and neuromuscular coordination were evaluated in mice. The anxiolytic effect of aqueous extract $(10,25,50,100 \mathrm{mg} / \mathrm{kg}$, ip) was examined in male albino mice using elevated plus-maze as an animal model of anxiety. The effects of the extract on spontaneous activity and neuromuscular coordination were assessed using Animex Activity Meter and rotarod. In the elevated plus-maze, $100 \mathrm{mg} / \mathrm{kg}$ of the aqueous extract showed an anxiolytic effect by increasing the time spent on open arms and the percentage of open arm entries, compared to control group. Aqueous extract at 50, 100 and 500 $\mathrm{mg} / \mathrm{kg}$ significantly reduced spontaneous activity and neuromuscular coordination, compared to control group [51-52].

The aqueous, hydroalcoholic extracts and essential oil of coriander seeds possessed sedative-hypnotic activity. The aqueous, hydroalcoholic extracts and essential oil of coriander seeds $(100,200,400$ and $600 \mathrm{mg} / \mathrm{kg})$ were intraperitoneally administered to male albino mice, 30 minutes before pentobarbital injection ( $40 \mathrm{mg} / \mathrm{kg})$. Latency to sleep and sleep duration were recorded. Aqueous extract prolonged pentobarbital-induced sleeping time at 200, 400 and $600 \mathrm{mg} / \mathrm{kg}$. Hydroalcoholic extract at doses of 400 and $600 \mathrm{mg} / \mathrm{kg}$ increased pentobarbital induced sleeping time compared to saline-treated group. The essential oil increased pentobarbital-induced sleeping time only at $600 \mathrm{mg} / \mathrm{kg}$ [53]. 
The sleep-prolonging effect of Coriandrum sativum was investigated in mice. The hydroalcoholic extract (HAE) and its three fractions, water (WF), ethyl acetate (EAF) and N-butanol (NBF) were prepared from Coriandrum sativum aerial parts and administrated to mice. The HAE, EAF and NBF significantly prolonged sleep duration. Only the NBF was significantly decreased sleep latency. No decrease in the neuronal surviving was observed either by HAE or by its fractions. The data indicated that Coriandrum sativum exerted sleep-prolonging action without major neurotoxic effect [54].

\subsection{Crocus sativus}

The anxiolytic and hypnotic effects of saffron aqueous extract and its constituents, crocin and safranal were studied in mice. Agents were administered intraperitoneally in mice before the experiments for the evaluation of hypnotic activity (induced by sodium pentobarbital, $30 \mathrm{mg} / \mathrm{kg}$, ip), anxiolytic activity (elevated plus maze test), locomotor activity (open field test) and motor coordination (Rotarod test). The aqueous extract reduced the locomotor activity dose dependently. At low doses, saffron showed a significant increase in the time on the open arms of the maze. When using the Rotarod method, the aqueous extract showed considerable effect on motor coordination of the mice. In the hypnotic test, only a dose of $0.56 \mathrm{~g} / \mathrm{kg}$ of saffron increased the total sleep. Crocin showed no anxi olytic, hypnotic or myorelaxation effects. Safranal, in higher doses, 0.15 and $0.35 \mathrm{ml} / \mathrm{kg}$, showed anxiolytic effects. Safranal increased the total sleep time dose dependently. This constituent at lower doses $(0.05$ and $0.15 \mathrm{ml} / \mathrm{kg})$ decreased some locomotion activity parameters. Safranal demonstrated no effects on motor coordination. Based on the results, saffron aqueous extract and safranal showed anxiolytic and hypnotic effects [55].

Intragastric administration of $125-250 \mathrm{mg} / \mathrm{kg}$ bw of a $50 \%$ ethanol extract of the stigmas showed tranquillizing effect and potentiated the sedative effects of barbiturates in mice [56-57].

The anxiolytic properties of crocins was investgated in rodents via light/dark test. Crocins, at a dose which did not influence animals' motor activity (50 mg/kg), or diazepam $(1.5 \mathrm{mg} / \mathrm{kg})$, increased the rats latency to enter the dark compartment and prolonged the time spent in the lit chamber. Lower doses of crocin (15-30 mg/kg) did not modify animals behavior [58].

Antianxiety-like behavior of aqueous, ethanolic and acetonitrile Crocus sativus extracts have been investigated in forcedswimming stress in rats. Different doses of extracts $(10,30,60 \mathrm{mg} / \mathrm{kg}$ ) were injected intraperitoneally (ip) in a 9-day period, meanwhile, swimming stress was performed for 15 minutes in four sessions (days 3, 5, 7 and 9). The time performing the followings: immobility, swimming and struggling was measured. Moreover, free fatty acids, glucose, corticosterone and HSP70 were also measured. The outcomes demonstrated that saffron decreased stress significantly by prolonging immobility and decreasing the active behavior swimming, without much effect on struggling. The extracts also showed significant reduction in levels of the stress biomarkers. Acetonitrile was identified as the most effective extract in reducing anxiety. The saffron extracts probably proved anti-stress and sedative properties, partly due to distinct proportion and synergistic impact of the active constituents. On the other hand, crocin and safranal have antioxidant and anti-inflammatory powers that may aid to mediate this protective central impact [59].

The effects of saffron water extract and its constituent, safranal was studied on the behavioral and metabolic signs induced by electroshock stress in male Wistar. Animals were received intra-amygdala (1, 5, and $10 \mu \mathrm{g} / \mathrm{rat}) \mathrm{or}$ intraperitoneal $(1,5$, and $10 \mathrm{mg} / \mathrm{kg})$ of the extract, safranal, or saline 5 or $30 \mathrm{~min}$ before stress induction. The results showed that stress elevated the corticosterone plasma concentration (115 nmol/l) in the control and intra-amygdala $(1,5$, and $10 \mu \mathrm{g} / \mathrm{rat})$-treated groups but not in groups received extract or safranal (55 nmol/l) intraperitoneally (1, 5, and $10 \mathrm{mg} / \mathrm{kg}$ ). Moreover, anorexia was reduced only in groups received the extract (1, 5, and $10 \mathrm{mg} / \mathrm{kg}) \mathrm{or}$ safranal (1, 5 , and $10 \mathrm{mg} / \mathrm{kg}$ ) intraperitoneally (50 sec). Stress increased sniffing, rearing, locomotion, and coping time, which were decreased by intraperitoneal $(1,5$, and $10 \mathrm{mg} / \mathrm{kg})$ but not by intra-amygdala $(1,5$, and $10 \mu \mathrm{g} / \mathrm{rat})$ administration of saffron extract and safranal. The results revealed that saffron water extract and safranal had an important impact on the reduction of both metabolic and behavioral signs of stress in male rats [60].

\subsection{Cynodon dactylon}

The dried extracts of aerial parts of Cynodon dactylon were evaluated for CNS activities in mice. The ethanol extract of aerial parts of Cynodon dactylon (EECD) was found to cause significant depression in general behavioral profiles in mice. EECD also significantly potentiated the sleeping time in mice induced by standard pentobarbitone sodium, diazepam, and meprobamate in a dose dependant manner [61-62].

The effects of ethanol extract of aerial parts of Cynodon dactylon (EECD) were studied to investigate its CNS depressant pharmacological properties in the classical behavioral models (open-field, elevated plus maze-EPM, Rota-rod, and 
barbiturate-induced sleeping time) in mice. Extract was given in 50\% propylene glycol as a solvent, as a single dose of 50,75 and $100 \mathrm{mg} / \mathrm{kg}$ ip. No significant effect was evident on motor coordination of the animals in the rotarod test. On EPM, all the doses of EECD caused significant reduction in the time of permanence in the open arms. In addition, EECD increased the immobility time in the forced swimming test and potentiated pentobarbital-induced sleeping time in mice, confirmed a probable sedative and central depressant effect in the animals [63].

\subsection{Cyperus rotuntdus}

The ethanolic extract of Cyperus rotundus showed potent tranquilizing activity in many tests. It reduced the spontaneous motor activity, potentiated the pentobarbital narcosis and deranged the motor coordination and abolished the conditioned avoidance response in animals [64-65].

The behavioral studies on mice indicated CNS depressant activity of the ethanol extract of Cyperus rotundus. The ethanol extract of Cyperus rotundus significantly potentiated the sleeping time of mice induced by standard hypnotics (pentobarbitone sodium, diazepam, and meprobamate) in a dose dependent manner [66].

Four sesquiterpenes (beta-selinene, isocurcumenol, nootkatone and aristolone) and one triterpene (oleanolic acid) were isolated from the ethylacetate fraction of the rhizomes of Cyperus rotundus and tested for their ability to modulate gamma-aminobutyric acid $\left(\mathrm{GABA}_{\mathrm{A}}\right)$-benzodiazepine receptor function by radioligand binding assays using rat cerebrocortical membranes. Among these compounds, only isocurcumenol was found to inhibit [ $\left.{ }^{3} \mathrm{H}\right] \mathrm{Ro} 15-1788$ binding and enhance $\left[{ }^{3} \mathrm{H}\right]$ flunitrazepam binding in the presence of GABA. The results suggested that isocurcumenol may serve as a benzodiazepine receptor agonist and allosterically modulated GABAergic neurotransmission via enhancement of endogenous receptor ligand binding [67].

\subsection{Datura species}

$25 \mathrm{~g} / \mathrm{kg}$ of methanolic crude extract induced behavioural sleep patterns (EEG) similar to that of thiopental in rats [6869].

\subsection{Echium italicum}

The anxiolytic and hypnotic effects of the aqueous and ethanolic extracts of aerial parts of E. italicum was evaluated in mice. Mice were administered the extracts intraperitoneally before the start of the experiments for evaluation of hypnotic activity (induced by sodium pentobarbital, $30 \mathrm{mg} / \mathrm{kg}$, ip), anxiolytic activity (elevated plus-maze [EPM] test), locomotor activity (open field test), and motor coordination (rotarod test). The ethanolic and aqueous extracts of E. italicum, at doses of 1.2 and $2.1 \mathrm{~g} / \mathrm{kg}$, increased the percentage of time-spent and the percentage of arm entries in the open arms of the EPM and decreased the percentage of time-spent in the closed arms of the EPM. Both extracts decreased the pentobarbital-induced latency to sleep and significantly increased the total sleeping time induced by pentobarbital. Locomotor activity was affected by aqueous extracts and ethanolic extract (at higher doses). Both extracts showed no effect in the rotarod test. According to these results, both ethanolic and aqueous extracts of E. italicum showed anxiolytic and sedative activity but not muscle relaxant activity [70].

\subsection{Equisetum arvense}

Hydroalcoholic extract of Equisetum arvense (200 and $400 \mathrm{mg} / \mathrm{kg}$ ) increased the sleeping time (46\% and 74\% respectively) in the barbiturate-induced sleeping time [72].

The effects of sedative, pre-anesthetic and anti-anxiety of Equisetum arvense with diazepam were studied in rats. The extract of Equisetum arvense was given at doses of $(100,200,400 \mathrm{mg} / \mathrm{kg}$, ip) and Diazepam with dose of( $0.5 \mathrm{mg} / \mathrm{kg}$, ip). The hydroalcoholic extract of $E$. arvense caused a significant increase in ketamine induced sleep and showed anxiolytic, sedative and preanesthetic effects at a dose of $200 \mathrm{mg} / \mathrm{kg}$ i.p [73].

\subsection{Eschsholzia californica}

A multicenter, double-blind, randomized, placebo-controlled study was carried out in general practice offices in Paris, France and the Paris area. Men and women $(\mathrm{N}=264)$ with mild to moderate generalized anxiety disorder as diagnosed according to the DSMIII- $\mathrm{R}$ criteria participated. Patients received either 2 tablets of placebo or Sympathyl® (Laboratoire Innotech International, Arcueil, France) twice daily for 3 months. Sympathyl contains 75 mg of dry hydroalcoholic extract of the flowering head of hawthorn, $20 \mathrm{mg}$ of dry aqueous extract of California poppy, and $75 \mathrm{mg}$ of elemental magnesium. Efficacy was assessed by change in Hamilton anxiety scale total and somatic scores, change in patient self-assessment, number and percentage of responsive subjects (reduction of at least $50 \%$ in Hamilton or self- 
assessment score) and the physician's clinical global impression. Treatment produced a rapid and progressive fall in anxiety. There was a significant improvement in the total anxiety score $(\mathrm{P}=0.005)$, somatic score $(\mathrm{P}=0.054)$, and selfassessment $(\mathrm{P}=0.005)$ in patients taking Sympathyl for 3 months [75].

The aqueous extract of Eschsholzia californica reduced the behavioural parameters measured in a familiar environment test in mice (novelty preference, locomotion and rearings in two compartments test) at doses above $100 \mathrm{mg} / \mathrm{kg}$ and in non-familiar environment tests (staircase test) at doses above $200 \mathrm{mg} / \mathrm{kg}$. The aqueous extract of Eschsholzia californica at a dose a of $25 \mathrm{mg} / \mathrm{kg}$, E. californica also possessed anxiolytic action since it produced an increase of the number of steps climbed by mice in the staircase test (anticonflict effect) and that of the time spent by animals in the lit box when they were confronted with the light/dark choice situation [76-77].

\subsection{Foeniculum vulgare}

The anxiolytic activity of the essential oil of Foeniculum vulgare (50, 100, and 200 and $400 \mathrm{mg} / \mathrm{kg}$ doses) was studied in mice using elevated plus maze (EPM), staircase test (SCT) and open field test (OFT). In EPM test, 100 and $200 \mathrm{mg} / \mathrm{kg}$ doses of the essential oil significantly increased percent number of entries and time spent in open arms compared to control. In SCT these doses also reduced rearing significantly compared to controls, while only the $200 \mathrm{mg} / \mathrm{kg}$ dose significantly increased number of squares crossed at the center in the OFT test [78].

The anxiolytic activity of ethanolic extracts of Foeniculum vulgare fruit was evaluated by elevated plus maze, rota rod, open field test, and hole board model in mices. The efficacy of extract $(100-200 \mathrm{mg} / \mathrm{kg})$ was compared with standard anxiolytic drugs diazepam $(1 \mathrm{mg} / \mathrm{kg})$. Extract administered animals showed exploratory behavior with all tests similar to diazepam. The results showed that the extract significantly increased the number of entries and time spent in the open arm in the elevated plus maze apparatus. In open field test, the extract showed significant increase in number of rearings, assisted rearing and number of square crossed [79].

The anxiolytic activity of the crude ethanolic extract of Foeniculum vulgare was studied in albino mice by elevated plusmaze model. The extract at doses of $200 \mathrm{mg} / \mathrm{kg}$ and $400 \mathrm{mg} / \mathrm{kg}$ has been found to possess significant anti-anxiety activity on the tested experimental models. The extract $(400 \mathrm{mg} / \mathrm{kg})$ exhibited maximum anti-anxiety effect. At a higher dose the extract $(400 \mathrm{mg} / \mathrm{kg}$ ) showed increase number of entries and time spent in open arm of elevated plus-maze model. The effect produced by the extract was comparable to that of diazepam [80].

The anti-stress and memory-enhancing properties of $\mathrm{F}$. vulgare boiling water extract (50, $100 \mathrm{and} 200 \mathrm{mg} / \mathrm{kg}$, orally) were studied in experimental rats. Urinary levels of vanillylmandelic acid (VMA) and ascorbic acid in rats were used to evaluate anti-stress activity. Conditioned avoidance response was measured in normal and scopolamine-induced amnesic rats to study the memory-enhancing effects. Lipid peroxidation inhibition assay in liver and brain homogenates of rats was used to evaluate antioxidant activity. Daily administration of F. vulgare extract (50, 100 and $200 \mathrm{mg} / \mathrm{kg}$ body weight) $1 \mathrm{~h}$ prior to induction of stress significantly $(\mathrm{p}<0.05)$ altered the stress-induced urinary biochemical levels of VMA from $395.79 \pm 11.23$ to $347.12 \pm 12.28,311.21 \pm 12.48$ and $258.86 \pm 10.26 \mu \mathrm{g} / \mathrm{kg}$, respectively, in $24 \mathrm{~h}$, as well as ascorbic acid excretion levels from $65.74 \pm 9.42$ to $78.59 \pm 8.44,108.41 \pm 15.62$ and $125.82 \pm 16.94 \mu \mathrm{g} / \mathrm{kg}$ also within the same period, respectively. These changes occurred in a dose-dependent fashion, and the levels in the control groups were unchanged within the same period. The memory deficits induced by scopolamine ( $1 \mathrm{mg} / \mathrm{kg}$, ip) in rats was reversed by F. vulgare dose-dependently. The extract also exhibited potent antioxidant effect by inhibition of lipid peroxidation in both rat liver and brain homogenates to a greater extent than the standard antioxidant, ascorbic acid [81-82].

\subsection{Helianthus annuus}

The methanolic extract of Helianthus annuus seeds also caused moderate anxiolytic activity (light-dark box and elevated plus maze test). H. annuus showed moderate increase in the latency of entry into the light box with peak effect produced at the dose of $200 \mathrm{mg} / \mathrm{kg}$ ( $72 \pm 0.85$ seconds) compared to control (34 \pm 5.63 seconds). In respect of latency of entry into the light box and number of entries, the values for $H$. annuus showed moderately significant anxiolytic effect at the dose of both $100 \mathrm{mg} / \mathrm{kg}(63 \pm 0.62$ seconds) and $200 \mathrm{mg} / \mathrm{kg}(72 \pm 0.85$ seconds). H. annuus produced a significant increase in the time spent in the open arms with peak effect produced at the dose of $100 \mathrm{mg} / \mathrm{kg}(51 \pm 0.62$ seconds $)$ relative to control (30.23 \pm 0.62 seconds). In respect of entry into open arms, the extract at the dose of $100 \mathrm{mg} / \mathrm{kg}$ significantly $(\mathrm{p}<0.05)$ increased the number of entries compared to control. The number of entries into the closed arms was reduced by $H$. annuus at doses of 100 and $200 \mathrm{mg} / \mathrm{kg}$ [83-84]. 


\subsection{Jasminum sambac}

The anxiolytic and antidepressant activities of ethanolic extract of Jasminum sambac flowers were evaluated using elevated plus maze, actophotometer, froced swim test and tail suspension test in mice. The ethanolic extracts of flowers of Jasminum sambac at a dose of 200 and $400 \mathrm{mg} / \mathrm{kg}$ ip, significantly possessed antidepressant and anxiolytic activity [85].

The antistress activity of the methanolic extract of Jasminum sambac (MEJS) leaves was studied against swimming stress induced gastric ulceration in rats and swimming endurance test in mice. Swimming stress induced changes in Ulcer index and histopathology in rats were compared with the standard. The biochemical parameters such as urea, triglycerides, cholesterol, alkaline phosphatase, SGPT, SGOT etc were examined in stressed and treated groups of rats. MEJS at a dose of $100 \mathrm{mg} / \mathrm{kg}$ and $200 \mathrm{mg} / \mathrm{kg}$ po, exhibited good antistress effect in both tested models. MEJS reduced the incidence of gastric ulceration in stressed rats. It also prevented the biochemical changes induced by forced swimming stress such as increase in plasma alkaline phosphatase, SGPT, SGOT, Urea, Triglycerides and Cholesterol. The stress induced rise in cholesterol and urea levels were significantly lowered by the extract. Also, the stress induced rise in plasma enzyme levels of SGPT and SGOT were significantly reduced when treated with the methanolic extract of Jasminum sambac at $100 \mathrm{mg} / \mathrm{kg}$ and $200 \mathrm{mg} / \mathrm{kg}$ bw and was comparable with the standard drug Geriforte at $43 \mathrm{mg} / \mathrm{kg}$ bw. The MEJS treated animals also showed an increase in swimming endurance time, which was almost comparable with that of standard drug [86-87].

\subsection{Juglans regia}

The anxiolytic effect of hydroalcoholic extract of Juglans regia fruit (200 and $400 \mathrm{mg} / \mathrm{kg} \mathrm{bw}$ ) was studied on the basis of effect on exploration behaviour and anxiety in elevated plus maze, zero maze, and light-dark model. Juglans regia extract produced significant effect on exploration and time spent in open area of elevated plus maze and zero maze. Extract also increased time spent in lighten area in light and dark model. Increase in number of head twitches was also observed at selected doses [88-89].

\subsection{Lallemantia royleana}

The anxiolytic and sedative like effects of methanolic extract of Lallemantia royleana seeds (75, 100, 250 and $500 \mathrm{mg} / \mathrm{kg}$, orally) was studied in male mice. Behavioral tests such as open field, hole-board, elevated plus maze, light-dark box and staircase paradigm were used to screen anxiolytic activity. Diazepam $(1 \mathrm{mg} / \mathrm{kg}$, ip) was employed as standard. Behavioral tests for anxiety showed maximum increase in anxiolytic parameters at the dose of $250 \mathrm{mg} / \mathrm{kg}(\mathrm{p}<0.01)$ without altering exploratory behavior i.e. number of head-dips $54 \pm 3.1$, time spent in open arm percent $70 \pm 2.8$, entries in open arm percent $67.3 \pm 1.2$, percent time spent in light box $62 \pm 1.5$ and number of stairs ascend $16 \pm 2.1$ [90-91].

\subsection{Lawsonia inermis}

The methanolic extract of Lawsonia inermis was tested for anxiolytic potential using white dark box model in mice. The extract at a dose of $100 \mathrm{mg} / \mathrm{kg}$ ip, exhibited significant increase in time spent in light area with respect to control animals. The reduction in anxiety behavior, also demonstrated by significant increase in number of entries in the light compartment relative to the dark compartment of the testing apparatus [92-93].

\subsection{Lepidium sativum}

The effect of total alkaloid from seeds of Lepidium sativum (50, 150 and $250 \mathrm{mg} / \mathrm{kg}$, ip) on thiopental induced hypnosis (mice), locomotor activity (mice), motor coordination (mice), antianxiety (mice) and analgesic effect (rats) were investigated. The results revealed that the total alkaloid from seeds of Lepidium sativum considerably potentiated the thiopental induced hypnosis, decreased locomotor activity and motor coordination, and increased preference to plus maze open arm. The total alkaloid from seeds of Lepidium sativum also increased the reaction time in caudal immersion and decreased number of wriths in acetic acid induced writhing [94-95].

\subsection{Lippia nodiflora}

The ethanolic extract of Lippia nodiflora at both doses (250 and $500 \mathrm{mg} / \mathrm{kg}$ oraally) and its chloroform extract at a higher dose of $500 \mathrm{mg} / \mathrm{kg}$ produced significant central inhibitory (sedative), anticonvulsant and anxiolytic effecst in mice. The petroleum ether extract of the plant at both dose levels ( 250 and $500 \mathrm{mg} / \mathrm{kg}$ orally) did not produce any central effects [96-97]. 


\subsection{Lycopus europaeus}

The sedative effect of the methanolic extract $(100,200,400$, and $600 \mathrm{mg} / \mathrm{kg}$, po) of Lycopus europaeus was evaluated compared to diazepam in hole board and thiopental -induced sleeping time methods in mice. The hypnotic effect was evaluated at the doses of 800 and $1000 \mathrm{mg} / \mathrm{kg}$, op, via reduction in reestablishment time and number of head dips during the traction and hole-board tests. The methanolic extract of Lycopus europaeus produced significant sedative effect at the doses of 200 and $400 \mathrm{mg} / \mathrm{kg}$ po. Furthermore, the dose of $100 \mathrm{mg} / \mathrm{kg}$ did not decreased the reestablishment time effectively. In the hole-board test, a significant reduction in the number of head dips was recorded at the doses of 200,400 , and $600 \mathrm{mg} / \mathrm{kg}$ by oral route administration. The extract induced reduction in the time of onset of sleep induced by thiopental. The effects of the extract on onset of sleep at 800 and $1000 \mathrm{mg} / \mathrm{kg}$ were comparable to that of diazepam at $30 \mathrm{mg} / \mathrm{kg}$ [98-99].

\subsection{Mangifera indica}

The anxiolytic activity of the aqueous extract of the leaves of Mangifera indica was studied using an elevated plus maze model in rat and staircase model in mice. In elevated plus maze model, Mangifera indica leaves aqueous extract at a dose of 250 and $500 \mathrm{mg} / \mathrm{kg}$ caused significant increase in the time spent in open arm and number of entries in open arm Significant decrease in SOD, CAT levels and increase in lipid peroxidation level was observed in stressed rats. Mangifera indica leaves aqueous extract 250 and $500 \mathrm{mg} / \mathrm{kg}$ improved SOD, CAT, and controlled the lipid peroxidation in liver tissue. In staircase model, at dose of 250 and $500 \mathrm{mg} / \mathrm{kg}$, the leaves aqueous extract of Mangifera indica showed significant increase in the number of step climbed and decrease the number of rearing(100-101).

\subsection{Matricaria chamomilla}

Inhaling of chamomile oil lead to reduction in stress induced plasma ACTH in ovarectomized rats [102].

CNS activities of oral uses of seven vegetable extracts and their combinations were tested in mice.The results revealed that Matricaria chamomilla possessed sedative and anxiolytic effect [103].

As aroma therapy the essential oil of Matricaria chamomilla was recommended for emotional frustration, anger, irritability, agitation, sudden fits of rage, mood swings and anxiety. The essential oil of Matricaria chamomilla calmed the mind and promoted relaxation [104].

The sedative properties of Matricaria recutita were investigated in the presence and absence of flumazenil as a benzodiazepine receptors antagonist in rats. After 7 doses of morphine naloxone was injected for induction of morphine withdrawal syndrome which characterized by signs of climbing, jumping and face washing. M. recutita decreased significantly the number of climbing in comparison to control group $(\mathrm{P}<0.001)$, but it had not significant effect on other signs. Flumazenil increased significantly the signs of jumping $(\mathrm{P}<0.01)$, face washing $(\mathrm{P}<0.05)$ in comparison to control group. M. recutita in the presence of flumazenil had not sedative effect and the climbing behavior increased significantly $(\mathrm{P}<0.05)[105]$.

\subsection{Melilotus officinalis}

The sedative effect of Melilotus officinalis extract was evaluated using a model of prolongation of hypnotic time of pentobarbital sodium in mice. Sedative action was recognized markedly in mice treated by the extract [106]. The antianxiety effect of petroleum ether, chloroform, ethanol, and water extracts $(50,100$, and $200 \mathrm{mg} / \mathrm{kg}$, po) of roots and aerial parts of Melilotus officinalis was studied in mice, using elevated plus maze (EPM) and mirrorchamber models of anxiety. The ethanol extract repared from aerial parts at 100 and $200 \mathrm{mg} / \mathrm{kg}$ showed a significant anxiolytic effect as compared to control and standard treatment group. The petroleum ether, chloroform, and water extracts (50, 100, and $200 \mathrm{mg} / \mathrm{kg}$ ) of the aerial parts of the plant did not produce antianxiety effect [107-108].

\subsection{Melissa officinalis}

The methanol extract of Melissa officinalis was identified as a potent in vitro inhibitor of rat brain GABA transaminase (GABA-T), an enzyme target in the therapy of anxiety, epilepsy and related neurological disorders, the effects could be attributed to rosmarinic acid which represented approximately $1.5 \%$ of the dry mass of the leaves [109].

The anxiolytic properties of Melissa officinalis and Valeriana officinalis (three separate single doses: $600 \mathrm{mg}, 1200 \mathrm{mg}$, $1800 \mathrm{mg}$ of a standardized product containing Melissa officinalis and Valeriana officinalis extracts) was studied in laboratory-induced stress in healthy volunteers. The results showed that the $600 \mathrm{mg}$ dose of the combination, ameliorated the negative effects of the Defined Intensity Stressor Simulation (DISS) on ratings of anxiety. However, the 
highest dose (1800 mg) showed an increase in anxiety that was less marked but which reached significance during one testing session. In addition, all three doses led to decrements in performance on the Stroop task module within the battery, and the two lower doses led to decrements on the overall score generated on the DISS battery [110].

Melissa officinalis, showed sedative properties in low doses by decreasing of behavioral parameters measured in a nonfamiliar environment test (staircase test) and in a familiar environment test (two compartment test). A lyophilised hydroalcoholic extract of Melissa officinalis showed peripheral analgesic activity by reducing the acetic acid-induced pain (writhing test) [111].

The effects of oral chronic treatment (15 consecutive days) of Melissa officinalis extract (Cyracos, Naturex) was investigated on anxiety-like reactivity in mice. Cyracos significantly reduced anxiety-like reactivity in the elevated plus maze dose-dependently, but no significant effect was observed in the open field task. However, Cyracos dose at which it exerted anxiolytic-like effects in the elevated plus maze did not alter exploratory or circadian activities [112].

\subsection{Myrtus communis}

The sedative- hypnotic effect of the aqueous extract was evaluated in mice. The aqueous extract of myrtle in dose of 200 $\mathrm{mg} / \mathrm{kg}$ ip, significantly reduced locomotor activity in open field test $(\mathrm{P}<0.01)$. A significant hypnotic effect of aqueous exract of myrtle was recorded in pentobarbital induced loss of righting reflex test $(p<0.05)$ [113].

\subsection{Nerium oleander}

The central nervous activity of $50 \%$ hydroalcoholic flower extract (100 and $200 \mathrm{mg} / \mathrm{kg}$ orally) of Nerium oleander was studied in mice. The locomotor activity was measured with an actophotometer, muscle relaxant activity by rotarod apparatus, the anticonvulsant activity by electroshock and pentyleneterazol- induced convulsion and sedative activity by potentiation of pentobarbital-induced sleep. The extract (at doses of 100 and $200 \mathrm{mg} / \mathrm{kg}$ ) significantly reduced ( $\mathrm{P}<$ $0.01)$ spontaneous locomotor activity and potentiated pentobarbital-induced sleep. At the higher dose $(200 \mathrm{mg} / \mathrm{kg}) \mathrm{the}$ extract showed $66 \%$ protection against electroshock-induced convulsions, while the lower dose (100mg/kg) produced a significant reduction $(\mathrm{P}<0.01)$ in pentylenetetrazol- induced convulsions [114-115].

\subsection{Nigella sativa}

The anxiolytic effect of Nigella sativa seed extracts of different germination phases was studied in experimental animals using both stressed and unstressed animal models. All the tested extracts of Nigella sativa (especially the extract of 5th day germination phase) showed significant $(\mathrm{P}<0.001)$ anxiolytic effect in comparison to control. Diazepam reduced locomotor activity in control (unstressed) rats but did not show affect in stressed rats while Nigella sativa extracts from germination phases significantly $(\mathrm{P}<0.001)$ reduced locomotor activity in unstressed as well as stressed animals [116].

The role of GABAergic and nitriergic modulation in the antianxiety effect of thymoquinone, was investigated in mice under unstressed and stressed conditions. Thymoquinone (10 and $20 \mathrm{mg} / \mathrm{kg}$ ), was administered followed by behavioral testing using an elevated plus maze, the light/dark test and the social interaction test in both unstressed and stressed mice. The effects of thymoquinone on plasma nitrite [a stable metabolite of nitric oxide (NO)] and brain GABA content were also studied. Thymoquinone $(10$ and $20 \mathrm{mg} / \mathrm{kg})$ produced significant antianxiety effects in unstressed mice without altering nitrite levels, but only the higher dose $(20 \mathrm{mg} / \mathrm{kg})$ of thymoquinone increased the GABA content in unstressed mice. In stressed mice, thymoquinone $(20 \mathrm{mg} / \mathrm{kg})$ showed anxiolytic effects, with a significant decrease in plasma nitrite and reversal of the decreased brain GABA content. According to the results, the study suggested an involvement of NO-cGMP and GABAergic pathways in the anxiolytic-like activity of thymoquinone [117].

The effect of thymoquinone on pentobarbital-induced hypnosis, locomotor activity, and motor coordination were studied in mice. Thymoquinone (40 and $80 \mathrm{mg} / \mathrm{kg}$ ) didn't show any hypnotic effect in the pentobarbital-induced hypnosis, but impaired the motor coordination and reduced the locomotor activity [118].

The aqueous and methanol extracts of Nigella sativa seeds were evaluated for their anxiolytic activity in rats by open field and elevated plus maze models. The rats exhibited an increase in open field activity and produced anti-anxiety effect in elevated plus maze. Oral administration of Nigella sativa oil increased brain 5-HT and tryptophan levels, and significantly decreased brain 5-HIAA level [119].

Cultured rat cortical neurons were exposed to different times and concentrations of Nigella sativa dry methanolic extract and the secretion of different amino acids was studied in primary cultured cortical neurons by high-performance liquid chromatography using a derivation before injection with dansyl chloride. Nigella sativa modulated amino acid 
release in cultured neurons; GABA was significantly increased whereas secretion of glutamate, aspartate, and glycine were decreased. These findings support the observed anxiolytic and sedative effects of Nigella sativa which could be based on changes of inhibitory/excitatory amino acids levels [120].

\subsection{Ocimum basilicum}

The anxiolytic and sedative activity of hydroalcoholic extract and essential oil of Ocimum basilicum (100, 150 and 200 $\mathrm{mg} / \mathrm{kg}$, and $200 \mathrm{mg} / \mathrm{kg}$, ip, $30 \mathrm{~min}$ before starting the experiment) were studied in mice using elevated plus maze and locomotor activity meter. The extract at 150 and $200 \mathrm{mg} / \mathrm{kg}$ and essential oil at $200 \mathrm{mg} / \mathrm{kg}$ significantly increased the time passed in open arms in comparison to control group. They didn't possess significant effect on the number of entrance to the open arms, but both decreased the locomotion of mice in comparison to the control group [121].

The sedative effects of hydroalcoholic extract of Ocimum basilicum (25, 50, or $100 \mathrm{mg} / \mathrm{kg})$, ethyl acetate fraction (50 $\mathrm{mg} / \mathrm{kg}$ ), n-butanol fraction (50 mg/kg) and water fraction $(50 \mathrm{mg} / \mathrm{kg}$ ) were studied using sleepprolonging effect of pentobarbital- induced sleep in mice. The hydroalcoholic extract increased the duration of pentobarbital-induced sleep at doses of 25,50 , and $100 \mathrm{mg} / \mathrm{kg}(\mathrm{P}<0.001)$. The hypnotic effect of the extract was comparable to that induced by diazepam. Similarly, all fractions at $50 \mathrm{mg} / \mathrm{kg}$ also increased sleep duration. The sleep latency was decreased by the hydroalcoholic extract $(\mathrm{P}<0.01-<0.001)$ and butanol fraction $(\mathrm{P}<0.001)$ [122].

The sedative effect of Ocimum basilicum leaf essential oil was studied using thiopental- induced hypnosis in mice. Essential oils, at the doses of 10,50,100, or $200 \mathrm{mg} / \mathrm{kg}$ consistently decreased the latency for the onset of sleeping $(\mathrm{P}<0.01-0.001)$, and at the same doses, increased the sleeping time induced by thiopental $(10,50,100, \mathrm{and} 200 \mathrm{mg} / \mathrm{kg})$ $(\mathrm{P}<0.001)[123-124]$.

\section{Conclusion}

Natural therapy including herbs and medicinal plants has been used in the treatment of insomnia and anxiety since a long time. In this review. In this article, we have reviewed the detail about the medicinal plants with potential therapeutic values Insomnia and anxiety with emphasis on their mechanisms of action, as promising therapeutic remedies because of their effectiveness and safety.

\section{Compliance with ethical standards}

\section{Acknowledgments}

We acknowledged the dean of Thi qar college of medicine, and the dean of karbala college of medicine for the scientific support.

\section{Disclosure of conflict of interest}

The author confirm that the paper's content has no conflict of interests.

\section{Funding}

The author received no fund from any source.

\section{References}

[1] Al-Snafi AE. Traditional uses of Iraqi medicinal plants. IOSR Journal of Pharmacy. 2018; 8(8): $32-96$.

[2] Al-Snafi AE. Traditional uses of Iraqi medicinal plants (part 2). International Journal of Biological and Pharmaceutical Sciences Archive. 2021; 2(1): 22-41.

[3] Al-Snafi AE. Therapeutic properties of medicinal plants: a review of medicinal plants with central nervous effects (part 1). Int J of Pharmacology \& Toxicology. 2015; 5(3): 177-192.

[4] Al-Snafi AE. Medicinal plants with central nervous effects (part 2): plant based review. IOSR Journal of Pharmacy. 2016; 6(8): 52-75.

[5] Al-Snafi AE,Talab TA, Majid WJ. Medicinal plants with central nervous activity - An overview (Part 1). IOSR Journal of pharmacy. 2019; 9(3): 52-102. 
[6] Al-Snafi AE. Medicinal Plants with neuroprotective effects. GSC Biological and Pharmaceutical Sciences. 2021; 17(1): 213-231.

[7] Al-Snafi AE. Medicinal plants possessed anti-Parkinsonian effects with emphasis on their mechanisms of action. GSC Biological and Pharmaceutical Sciences. 2021; 17(1): 232-237.

[8] Al-Snafi AE. Medicinal plants possessed beneficial therapeutic effects in Alzheimer's disease and memory deficits. GSC Biological and Pharmaceutical Sciences. 2021; 17(02): 8-33.

[9] Al-Snafi AE. Medicinal plants with anticonvulsant activities with emphasis on their mechanisms of action. International Journal of Biological and Pharmaceutical Sciences Archive. 2021; 1(2): 177-189.

[10] Al-Snafi AE. A complementary and alternative natural antidepressant therapy with emphasis on their mechanisms of action. International Journal of Biological and Pharmaceutical Sciences Archive. 2021; 2(1): 7-21.

[11] Rossi T, Melegari M, Bianchi A, Albasini A and Vampa G. Sedative, anti-inflammatory and anti-diuretic effects induced in rats by essential oils of varieties of Anthemis nobilis: a comparative study. Pharmacol Res Commun. 1988; 20(5): 71-74.

[12] Viola H, Wasowski C, Levi de Stein M, Wolfman C, Silveira R, Dajas F, Medina JH, Paladini AC. Apigenin, a component of Matricariarecutita flowers, is a central benzodiazepine receptors-ligand with anxiolytic effects. Planta Medica. 1995; 61: 213-216.

[13] Al-Snafi AE. Medical importance of Anthemis nobilis (Chamaemelum nobilis)- A review. Asian Journal of Pharmaceutical Science \& Technology. 2016; 6(2): 89-95.

[14] Wang QC, Xu J, Shi M. Clinical efficacy of Groundnut leaves on insomnia treatments. Shanghai Journal of Traditional Chinese Medicine. 2001; 5: 8-10.

[15] Wang YF, Li HF, Xu YF, Zhang YL , Xu DS , Xiao LM, Li XM. Clinical confirmation of preparation from the branch and leaf of peanut in treating insomnia. Shanghai Journal of Traditional Chinese Medicine. 2001; 5: 8-10.

[16] Zu XY, Zhang ZY, Liu JQ, Hu HH, Xing GQ, Zhang Y, Guan D. Sedative effects of peanut (Arachis hypogaea L.) leaf aqueous extracts on brain ATP, AMP, Adenosine and Glutamate/GABA of rats. J Biomedical Science and Engineering. 2010; 3: 268-273.

[17] Al-Snafi AE. Chemical constituents and pharmacological activities of Arachis hypogaea - A review. International Journal for Pharmaceutical Research Scholars 2014; 3(1-1): 615-623.

[18] Dong WEI. Study on Anti-fatigue function of the extracts from Arctium lappa L. Journal of Anhui Agricultural Sciences. 2006; 23: 215.

[19] Al-Snafi AE. The Pharmacological importance and chemical constituents of Arctium Lappa. A review. International Journal for Pharmaceutical Research Scholars. 2014; 3(1-1): 663-670.

[20] Ye M R, Li R, Liao HF, Liao X Z, Huang GY. Pharmacological study on Asparagusofficinalis Linn. Zhongguo Zhong Yao Za Zhi. 1994;19(4): 240-242.

[21] Al-Snafi AE. The pharmacological importance of Asparagus officinalis - A review. Journal of Pharmaceutical Biology. 2015; 5(2): 93-98.

[22] Schellekens C, Perrinjaquet-Moccetti T, Wullschleger C, Heyne A. An extract from wild green oat improves rat behaviour. Phytother Res. 2009; 23(10): 1371-1377.

[23] Xu C, Lv J, Lo YM, Cui SW, Hu X, Fan M. Effects of oat $\beta$-glucan on endurance exercise and its anti-fatigue properties in trained rats. Carbohydr Polym. 2013; 92(2): 1159-1165.

[24] Vetvicka V, Dvorak B, Vetvickova J, Richter J, Krizan J, Sima PY, Vin JC. Orally administered marne (1 $\rightarrow 3)$ - $\beta$-glucan phycarine stimulates both humoral and cellular immunity. Int J of Biol Macromolecules. 2007; 40(4): $291-298$.

[25] Al-Snafi AE. The nutritional and therapeutic importance of Avena sativa - An Overview. International Journal of Phytotherapy. 2015; 5(1): 48-56.

[26] Reas SK, Amee K, Paulose CS. Glutamate receptor gene expression and binding studies in pilocarpine induced epileptic rat: neuroprotective role of Bacopa monnieri extract. Epilep Behav. 2008; 12: 54-60.

[27] Sheikh N, Ahmad A, Siripurapu KB, Kuchibhotla VK, Singh S, Palit G. Effect of Bacopa monniera on stress induced changes in plasma corticosterone and brain monoamines in rats. J Ethnopharmacol. 2007; 111: 671-676. 
[28] Bhattacharya SK, Ghoshal S. Anxiolytic activity of a standardized extract of Bacopa monniera: an experimental study. Phytomedicine. 1998; 5: 77-82.

[29] Rauf K, Subhan F, Abbas M, ul Haq I, Ali G and Ayaz M. Effect of acute and sub chronic use of Bacopa monnieri on dopamine and serotonin turnover in mice whole brain. African Journal of Pharmacy and Pharmacology. 2012; 6(39): 2767-2774.

[30] Al-Snafi AE. The pharmacology of Bacopa monniera. A review. International Journal of Pharma Sciences and Research. 2013; 4(12): 154-159.

[31] Bertrand MC, Tillequin F, Bailleul F. Two major flavonoids from Ballota nigra. Biochemical Systematics and Ecology. 2000; 28: 1031-1033.

[32] Vrchovska V, Spilkova J, Valentao P, Sousa C, Andrade PB, Seabra RM. Antioxidative properties and phytochemical composition of Ballota nigra infusion. Food Chem. 2007; 105: 1396-1403.

[33] Daels-Rakotoarison DA, Seidel V, Gressier B, Brunet C, Tillequin F, Bailleul F, Luyckx M, Dine T, Cazin M, Cazin JC. Neurosedative and antioxidant activities of phenylpropanoids from Ballota nigra. Arzneimittelforschung. 2000; $50(1): 16-23$.

[34] Al-Snafi AE. The Pharmacological Importance of Ballota nigra -A review. Ind J of Pharm Sci \& Res. 2015; 5(4): 249-256.

[35] Pal S, Sen T, Nag Chaudhari AK. Neuropsychopharmacological profile of the methanolic fraction of Bryophyllum Pinnatum leaf extract. Journal of Pharmacy and Pharmacology. 1999; 51: 313-318.

[36] Salahdeen HM, Yemitan OK. Neuropharmacological effects of Aqueous leaf extract of Bryophyllum pinnata in Mice. African Journal of Biomedical Research. 2006; 9: 101-07.

[37] Al-Snafi AE. The Chemical constituents and pharmacological effects of Bryophyllum calycinum-A review. Journal of Pharma Sciences and Research. 2013; 4(12): 171-176.

[38] Ali A, Rao NV, Shalam M, Gouda TS, Babu JM, Shantakumar S. Anxiolytic activity of seed extract of Caesalpinia Bonducella (Roxb) in laboratory animals. The Internet Journal of Pharmacology. 2008; 5: 1531.

[39] Kannur DM, Hukkeri VI, Akki K. Adaptogenic activity of Caesalpinia bonducella seed extracts in rats. Journal of Ethnopharmacology 2006; 108: 327-331.

[40] Al-Snafi AE. Pharmacology and medicinal properties of Caesalpinia crista - An overview. International Journal of Pharmacy. 2015; 5(2): 71-83.

[41] Koppula S, Kopalli SR and Sreemantula S. Adaptogenic and nootropic activities of aqueous extracts of Carum carvi Linn (caraway) fruit: an experimental study in Wistar rats. Australian Journal of Medical Herbalism. 2009; 1(3): 72-78.

[42] Al-Snafi AE. The chemical constituents and pharmacological effects of Carum carvi - A review. Indian Journal of Pharmaceutical Science and Research. 2015; 5(2): 72-82.

[43] Li R, Wang X, Qin T, Qu R, Ma S. Apigenin ameliorates chronic mild stress-induced depressive behavior by inhibiting interleukin-1 $\beta$ production and NLRP3 inflammasome activation in the rat brain. Behav Brain Res. 2016; 296: 318-325.

[44] Lopes C, Gonçalves eSá C, de Almeida AA, da Costa JP, Marques TH, Feitosa CM, Saldanha GB, de Freitas RM. Sedative, anxiolytic and antidepressant activities of Citrus limon (Burn) essential oil in mice. Pharmazie. 2011; 66(8): 623-627.

[45] Faturi CB, Leite JR, Alves PB, Canton AC, Teixeira-Silva F. Anxiolytic - like effect of sweet orange aroma in Wistar rats. Prog Neuropsychopharmacolo Biol Psych. 2010; 34(4): 605-609.

[46] Al-Snafi AE. Nutritional value and pharmacological importance of citrus species grown in Iraq. IOSR Journal of Pharmacy. 2016; 6(8): 76-108.

[47] Pathan AR, Kothawade KA, Logade MN. Anxiolytic and analgesic effect of seeds of Coriandrum sativum Linn. IJRPC. 2011; 1(4): 1087-1099.

[48] Al-Snafi AE. A review on chemical constituents and pharmacological activities of Coriandrum sativum. IOSR Journal of Pharmacy. 2016; 6(7): 17-42. 
[49] Latha K, Rammohan B, Sunanda BP, Maheswari MS, Mohan SK. Evaluation of anxiolytic activity of aqueous extract of Coriandrum sativum Linn in mice: A preliminary experimental study. Pharmacognosy Res. 2015; 7(Suppl 1): S47-51.

[50] Mahendra P, Bisht S. Anti-anxiety activity of Coriandrum sativum assessed using different experimental anxiety models. Indian J Pharmacol. 2011; 43(5): 574-577.

[51] Emamghoreishi M, Khasaki M, Aazam MF. Coriandrum sativum has anxiolytic and potentially sedative and muscle relaxant effects. Mol Cancer Ther. 2007; 6(3): 1013-1021.

[52] Emamghoreishi M, Khasaki M, Aazam MF. Coriandrum sativum: evaluation of its anxiolytic effect in the elevated plus-maze. J Ethnopharmacol. 2005; 96(3): 365-370.

[53] Emamghoreishi M, Heidari-Hamedani G. Sedative-hypnotic activity of extracts and essential oil of coriander seeds. Iran J Med Sci. 2006; 31(1): 22-27.

[54] Rakhshandeh H, Sadeghnia HR, Ghorbani A. Sleep-prolonging effect of Coriandrum sativum hydro-alcoholic extract in mice. Nat Prod Res. 2012; 26(22): 2095-2098.

[55] Hosseinzadeh H, Noraei NB. Anxiolytic and hypnotic effect of Crocus sativus aqueous extract and its constituents, crocin and safranal, in mice. Phytother Res. 2009; 23(6): 768-774.

[56] Zhang Y, Shoyama Y, Sugiura M, Saito H. Effects of Crocus sativus L. on the ethanol-induced impairment of passive avoidance performances in mice. Biological and Pharmaceutical Bulletin. 1994; 17(2): 217-221.

[57] Al-Snafi AE. The pharmacology of Crocus sativus- A review. IOSR Journal of Pharmacy. 2016; 6(6): 8-38.

[58] Pitsikas N, Boultadakis A, Gergiadou G, Tarantilis PA, Sakellaridis N. Effects of the active constituents of Crocus sativus L. in an animal model of anxiety. Phytomedicine. 2008; 15: 1135-1139.

[59] Mobarakeh JI, Fakhraei N, Sadr ZA, Hamidipour A, Mostafavi E, Hosseini RH, Sardari S. Effect of aqueous, ethanolic and acetonitrile Crocus sativus L. extracts on stress biomarkers in male rats. Journal of Medicinal Plants Research. 2013; 7(44): 3269-3279.

[60] Hooshmandi Z, Rohani AH, Eidi A, Fatahi Z, Golmanesh L, Sahraei H. Reduction of metabolic and behavioral signs of acute stress in male Wistar rats by saffron water extract and its constituent safranal. Pharm Biol. 2011; 49(9): 947-954.

[61] Pal D. Evaluation of CNS activities of aerial parts of Cynodon dactylon Pers in mice. Drug Research 2008; 65(1): 37-43.

[62] Al-Snafi AE. Chemical constituents and pharmacological effects of Cynodon dactylon- A review. IOSR Journal of Pharmacy. 2016; 6(7): 17-31.

[63] Sonawane S, Bharati D, Undale VR, Bhosale AV. Central nervous system depressant activity of ethanol extract of aerial parts of Cynodon dactylon (L) Pers (Durva) in mice. Res J Pharmacognosy and Phytochemistry. 2009; 1(2): 119-122.

[64] Singh N, Kulshrestha VK, Gupta MB, Bhargava KP. A pharmacological study of Cyperus rotundus. Indian J Med Res. 1970; 58: 103-109.

[65] Al-Snafi AE. A review on Cyperus rotundus A potential medicinal plant. IOSR Journal Of Pharmacy. 2016; 6(7): 32-48.

[66] Pal D, Dutta S, Sarkar A. Evaluation of CNS activities of ethanol extract of roots and rhizomes of Cyperus rotundus in mice. Acta Pol Pharm. 2009; 66(5): 535-541.

[67] Ha JH, Lee KY, Choi HC, Cho J, Kang BS, Lim JC, Lee DU. Modulation of radioligand binding to the GABAAbenzodiazepine receptor complex by a new component from Cyperus rotundus. Biol Pharm Bull. 2002; 25(1): 128-130.

[68] Babalola SA, Suleiman MM, Hassan AZ, Adawa DAY. Evaluation of Datura Metel L seed extract as a sedative/hypnotic: a priliminary study. J Vet Adv. 2015; 5(4): 857-862.

[69] Al-Snafi AE. Medical importance of Datura fastuosa (syn: Datura metel) and Datura stramonium - A review. IOSR Journal of Pharmacy. 2017; 7(2): 43-58.

[70] Hosseinzadeh H, Shahandeh S, Shahsavand S. Anxiolytic and hypnotic effects of aqueous and ethanolic extracts of aerial parts of Echium italicum L. in mice. Jundishapur J Nat Pharm Prod. 2012; 7(2): 71-79. 
[71] Al-Snafi AE. Pharmacological and therapeutic importance of Echium italicum- A review. Indo Am J P Sci. 2017; 4(02): 394-398.

[72] Dos Santos Jr JG, Blancoa MM, Do Monteb FHM, Russib M, Lanziottib VNMB, Lealc LKAM, Cunhac GM. Sedative and anticonvulsant effects of hydroalcoholic extract of Equisetum arvense. Fitoterapia. 2005; 76(6): 508-513.

[73] Rezaie A, Ahmadizadeh C, Mosavi G, Nazeri M, Jafari B, Ebadi R. Comparative study of sedative, pre-anesthetic and anti-anxiety effect of Equisetum arvense (horse's Tail) extract with diazepam on rats. Australian Journal of Basic and Applied Sciences 2011; 5(10): 786-789.

[74] Al-Snafi AE. The pharmacology of Equisetum arvense- A review. IOSR Journal of Pharmacy 2017; 7(2): $31-42$.

[75] Hanus M, Lafon J and Mathieu M. Double-blind, randomised, placebo-controlled study to evaluate the efficacy and safety of a fixed combination containing two plant extracts (Crataegus oxyacantha and Eschscholtzia californica) andmagnesium in mild-to-moderate anxiety disorders. Current Medical Research and Opinion 2004; 20(1): 6371.

[76] Rolland A, Fleurentin J, Lanhers MC, Younos C, Misslin R, Mortier F and Pelt JM. Behavioural effects of the American traditional plant Eschscholzia californica: sedative and anxiolytic properties. Planta Medica 1991; 57(3): 212-216.

[77] Al-Snafi AE. Eschscholzia californica: A phytochemical and pharmacological review. Indo Am J P Sci. 2017; 4(02): 257-263.

[78] Mesfin M, Asres K, Shibeshi W. Evaluation of anxiolytic activity of the essential oil of the aerial part of Foeniculum vulgare Miller in mice. BMC Complement Altern Med. 2014; 14: 310.

[79] Kishore RN, Anjaneyulu R, Ganesh NN, Sravya N. Evaluation of anxiolytic activity of ethanolic extract of oeniculum vulgare in mice model. International Journal of Pharmacy \& Pharmaceutical Sciences. 2012; 4(3): $584-586$.

[80] Divekar A, Oswal RJ, Bagul YR, Antre RV, Pune W. The pharmacological evaluation of Foeniculum vulgare Miller for anti-anxiety. Imperial J Pharmacology \& Toxicology. 2011; 1(1): 16.

[81] Koppula S, Kumar H. Foeniculum vulgare Mill (Umbelliferae) attenuates stress and improves memory in wister rats. Tropical Journal of Pharmaceutical Research. 2013; 12 (4): 553-558.

[82] Al-Snafi AE. The chemical constituents and pharmacological effects of Foeniculum vulgare - A review. IOSR Journal of Pharmacy. 2018; 8(5): 81-96.

[83] Islam RT, Islam AT, Hossain MM, Mazumder K. Central nervous system activity of the methanol extracts of Helianthus annuus seeds in mice model. International Current Pharmaceutical Journal. 2015; 5(1): 1-4.

[84] Al-Snafi AE. The pharmacological effects of Helianthus annuus- A review. Indo Am J P Sc. 2018; 5(3): $1745-1756$.

[85] Rambabu B, Patnaik KR. Anxiolytic and antidepressant activities of ethanolic extracts of Jasminum Sambac, Chamomilla capitula, Lilium candidum, Sorghum helpense flowers. International Journal of Advances in Pharmaceutical Sciences. 2016; 7(3): 3108-3114.

[86] Baby AA. Pharmacological investigations of antistress Activity of jasminum sambac (linn) leaves. 2010.

[87] Al-Snafi AE. Pharmacological and therapeutic effects of Jasminum sambac- A review. Indo Am J P Sc. 2018; 5(3): 1766-1778.

[88] Chandel HS, Singh S, Pawar A. Neuropharmacological investigation of Juglans regia fruit extract with special reference to anxiety. Int J Drug Res Tech. 2012; 2(7): 461-471.

[89] Al-Snafi AE. Chemical constituents, nutritional, pharmacological and therapeutic importance of Juglans regia- A review. IOSR Journal of Pharmacy. 2018; 8(11): 1-21.

[90] Hyder N, Musharraf SG, Shyum Naqvi SB. Diazepam-like effects of Lallementia royleana Benth. (Lamiaceae) seeds in anxiety disorder. Journal of the Neurological Sciences. 2017; 381: 607-608.

[91] Al-Snafi AE. Pharmacological and Therapeutic effects of Lallemantia royleana- A review. IOSR Journal of Pharmacy. 2019; 9(6): 43-50.

[92] Ahmed S, Iqbal J. Aniolytic effect of Lawsonia inermis (henna) on light dark boxactivity. World Journal of Pharmacy and Pharmaceutical Sciences. 2014; 3(5): 1334-1339.

[93] Al-Snafi AE. A review on Lawsonia inermis: A potential medicinal plant. International Journal of Current Pharmaceutical Research. 2019; 11(5): 1-13. 
[94] Shukla A, Chandra SS, Papiya B. Phytochemical and CNS activity of Lepidium sativum Linn seeds total alkaloid. Scholar Research Library. 2011; 3(2): 226-237.

[95] Al-Snafi AE. Chemical constituents and pharmacological effects of Lepidium sativum- A review. International Journal of Current Pharmaceutical Research. 2019; 11(6): 1-10.

[96] Thirupathy KP, Tulshkar A, Vijaya C. Neuropharmacological activity of Lippia nodiflora Linn. Pharmacognosy Research. 2011; 3(3): 194-200.

[97] Al-Snai AE. Pharmacological and therapeutic effects of Lippia nodiflora (Phyla nodiflora). IOSR Journal of Pharmacy. 2019; 9(8): 15-25.

[98] Abdul Aziz, Khan IA. Pharmacological evaluation of sedative and Hypnotic activities of methanolic extract of Lycopus europaeus in mice. The Journal of Phytopharmacology. 2013; 2(4): 8-12.

[99] Al-Snai AE. A review on Lycopus europaeus: A potential medicinal plant. IOSR Journal of Pharmacy. 2019; 9(7): 80-88.

[100] Patel NB, Kumar S, Prasad AK, Patel JA, Patel HA. Assessment of anxiolytic activity of aqueous extract of Mangifera indica L leaves in rodents exposed to chronic unpredictable mild stress. IRJP. 2013; 4(1): 247-251.

[101] Al-Snafi AE, Ibraheemi ZAM, Talab TA. A review on components and pharmacology of Mangifera indica. International Journal of Pharmaceutical Research. 2021; 13(2): 3043- 3066.

[102] Gibbs RS, Karlan BY, Haney AF, Nygaard RE. Danforth's obstetrics and gynecology. Ketabarjomand, Tehran 2008.

[103] Della Loggia R, Tubaro A, Redaelli C. Evaluation of the activity on the mouse CNS of several plant extracts and a combination of them. Riv Neurol. 1981; 51(5): 297-310.

[104] Holmes P. Aromatica- A clinical guide to essential oils therapeutics. Volume 1: Principles and profiles. Singing Dragon, London. 2016.

[105] Kesmati M, Abbasi Zadeh Z, Fathi Moghaddam H. Study of benzodiazepine like effects of Matricaria recutita on morphine withdrawal syndrome in adult male rats. Pak J Med Sci. 2008; 24(5): 735-739.

[106] Hong ND, Won DH and Kim NJ. Pharmacological studies on Melilotus officinalis extract. Korean Journal of Pharmacognosy 1983; 14(2): 51-59.

[107] Kaur S, Sharma A and Bedi PMS. Evaluation of anxiolytic effect of Melilotus officinalis extracts in mice. Asian Journal of Pharmaceutical and Clinical Research 2017;10(6):396-399.

[108] Al-Snafi AE. Chemical constituents and pharmacological effects of Melilotus officinalis- A review. IOSR Journal of Pharmacy 2020; 10(1):26-36.

[109] Awad R, Muhammad A, Durst T, et al. Bioassay-guided fractionation of lemon balm (Melissa officinalis L.) using an in vitro measure of GABA transaminase activity. Phytother Res 2009; 23(8):1075-1081.

[110] Kennedy DO, Little W, Haskell CF and Scholey AB. Anxiolytic effects of a combination of Melissa officinalis and Valeriana officinalis during laboratory induced stress. Phytother Res 2006; 20(2):96-102.

[111] Soulimani R, Fleurentin J, Mortier F, Misslin R, Derrieu G and Pelt JM. Neurotropic action of the hydroalcoholic extract of Melissa officinalis in the mouse. Planta Med 1991; 57(2):105-109.

[112] Ibarra A, Feuillere N, Roller M, et al. Effects of chronic administration of Melissa officinalis L extract on anxietylike reactivity and on circadian and exploratory activities in mice. Phytomedicine. 2010; 17(6): 397-403.

[113] Shahmohammadi Z, Sojoodi moghaddam M, Kamalinejad M, Faizi M. Evaluation of sedative-hypnotic effect of Myrtus communis L. aqueous extract in mice. Research in Pharmaceutical Sciences. 2012; 7(5): S832.

[114] Singhal KG, Gupta GD. Some central nervous system activities of Nerium oleander linn (Kaner) flower extract. Trop J Pharm Res. 2011; 10(4): 455-461.

[115] Al-Snafi AE. Bioactive ingredients and pharmacological effects of Nerium oleander. IOSR Journal of Pharmacy. $2020 ; 10(9): 19-32$.

[116] Islam MH, Ahmad IZ, Salman MT. Neuroprotective effects of Nigella sativa extracts during germination on central nervous system. Pharmacogn Mag. 2015; 11(Suppl 1): S182-189.

[117] Gilhotra N, Dhingra D. Thymoquinone produced antianxiety-like effects in mice through modulation of GABA and NO levels. Pharmacol Rep. 2011; 63: 660-669. 
[118] Hosseinzadeh H, Parvardeh S. Anticonvulsant effects of thymoquinone, the major constituent of Nigella sativa seeds, in mice. Phytomedicine. 2004; 11: 56-64.

[119] Perveen T, Haider S, Kanwal S, Haleem DJ. Repeated administration of Nigella sativa decreases 5-HT turnover and produces anxiolytic effects in rats, Pak J Pharm Sci. 2009; 22(2): 139-44.

[120] El-Naggar T, Gómez-Serranillos MP, Palomino OM, Arce C, Carretero ME. Nigella sativa L. seed extract modulates the neurotransmitter amino acids release in cultured neurons in vitro. J Biomed Biotechnol. 2010; 398312.

[121] Rabbani M, Sajjadi SE, Vaezi A. Evaluation of anxiolytic and sedative effect of essential oil and hydroalcoholic extract of Ocimum basilicum L. and chemical composition of its essential oil. Res Pharm Sci. 2015; 10(6): 535543.

[122] Askari VR, Baradaran Rahimi V, Ghorbani A, Rakhshandeh H. Hypnotic effect of Ocimum basilicum on pentobarbital- induced sleep in mice. Iran Red Crescent Med J. 2016; 18(7): e24261.

[123] Oliveira SJ, Porto AL, Estevam SC, Siqueira SR, Alves BP, Niculae SE, Blank FA, Almeida NR, Marchioro M, Junior QJL. Phytochemical screening and anticonvulsant property of Ocimum basilicum leaf essential oil. Boletin Latinoamericano y del Caibe de Plantas Medicinales y Aromaticas. 2009; 8(3): 195-202.

[124] Al-Snafi AE. Chemical constituents and pharmacological effects of Ocimum basilicum- A review. International Journal of Pharmaceutical Research. 2021; 13(2): 2997-3013. 